\title{
Progressing haemolysis, elevated liver enzymes, low platelet count syndrome: near miss case
}

\author{
Urvashi Verma $^{1}$, Shruti Agarwal ${ }^{1 *}$, Sangita Sahu$^{1}$, Ajit Chahar ${ }^{2}$
}

\begin{abstract}
${ }^{1}$ Department of Obstetrics and Gynecology, S. N. Medical College, Agra, Uttar Pradesh, India
${ }^{2}$ Department of Medicine, S. N. Medical College, Agra, Uttar Pradesh, India
\end{abstract}

Received: 19 February 2020

Revised: 29 February 2020

Accepted: 27 March 2020

\author{
*Correspondence: \\ Dr. Shruti Agarwal, \\ E-mail: drshrutiagarwal12june@gmail.com
}

Copyright: (c) the author(s), publisher and licensee Medip Academy. This is an open-access article distributed under the terms of the Creative Commons Attribution Non-Commercial License, which permits unrestricted non-commercial use, distribution, and reproduction in any medium, provided the original work is properly cited.

\begin{abstract}
A 25 years old women presented in labour room with 30 weeks' pregnancy in labour with breech with previous two caesarean section and scar tenderness with foetal bradycardia (FHR 90) and jaundice. After caesarean section in emergency hour she started bleeding in abdominal drain while uterus was well contracted. On investigation and examination diagnosed as HELLP syndrome, managed promptly by medical teams of three departments (obstetrician, anaesthesia and medicine).
\end{abstract}

Keywords: Acute fatty liver of pregnancy, Elevated liver enzymes, Hemolytic uremic syndrome, Low platelet count, HELLP syndrome

\section{INTRODUCTION}

One of the most common complications in pregnancy is hypertensive disorders with one of the most serious expressions of this pathology being HELLP syndrome. The HELLP syndrome is characterized by the presence of a triad: microangiopathic haemolysis, elevated liver enzymes and low platelet count. ${ }^{1}$ Differential diagnosis could be acute fatty liver of pregnancy, thrombotic thrombocytopenic purpura, antiphospholipid syndrome and haemolytic uremic syndrome. ${ }^{2}$ The mainstay of treatment involves maternal stabilization and timely delivery. In some patients with HELLP syndrome, activation of coagulation factors and platelets leads to disseminated intravascular coagulation, which in a few becomes uncompensated and contributes to lifethreatening multi organ failure.

\section{CASE REPORT}

A 25-year-old married average built Hindu female (G3P2L1A0) laborer by occupation was admitted in the hospital in emergency with chief complaint of amenorrhea of eight months, pain in abdomen for one day and slight bleeding per vagina for 8 to 10 hours. She had a history of previous two caesarean section with last birth one and half year back only. She had one live issue and single antenatal visit in present pregnancy. At the time of admission her blood pressure was $150 / 100 \mathrm{mmHg}$, pulse rate was $90 / \mathrm{min}$, non-febrile, $\mathrm{SpO}_{2}$ was $98 \%$ on room air, urine albumin was +1 . On general examination pallor was +1 , icterus was +3 , cyanosis, clubbing, lymphadenopathy were not present. The patient was not on any antihypertensive or any other medication of any type. No clinically significant edema, right upper quadrant or epigastric pain, dyspnoea, visual disturbance was present. On par abdomen examination fundal height of 30 weeks' pregnancy with breech presentation had uterine contraction one per 10 minutes of moderate intensity with scar tenderness with FHS of 92 beats/min. The only scan she had of 10 days back showed a single live intra uterine foetus of 29 weeks 2 days, with anterior placenta, adequate liquor and scar thickness of $3.6 \mathrm{~mm}$. she was taken for emergency CS along with investigations and blood arrangement simultaneously. Intra operatively abdominal adhesions were present and an alive preterm 
low birth weight female baby weighing $1.1 \mathrm{~kg}$ was taken out by breech presentation. No active bleeding was there during caesarean section in spite of that a drain was kept in situ. Abdomen was closed in layers. Patient was shifted to post-op room for monitoring. One-unit blood arranged and transfused par operatively. Post-op vitals were normal. Within an hour of caesarean section her drain bag was filled with $200 \mathrm{ml}$ bloody discharge. Uterus was well contracted with no active vaginal bleeding. Vitals and urine output were normal. Abdomen was soft no distension was there.

\section{Day 1 pre-op investigations}

- Hemoglobin - $12.5 \mathrm{~g} / \mathrm{dl}$

- TLC- $16900 \mathrm{cell} / \mathrm{mm}^{3}$

- Platelet count- $0.50 \mathrm{lac} / \mathrm{mm}^{3}$

- RDW- $20.2 \%$

- $\quad \mathrm{S} . \mathrm{Bb}$ (Total) $-9.85 \mathrm{mg} / \mathrm{dl}$

- $\quad \mathrm{S} . \mathrm{Bb}$ (Direct) - $5.88 \mathrm{mg} / \mathrm{dl}$

- $\quad \mathrm{S} . \mathrm{Bb}$ (Indirect) - $3.97 \mathrm{mg} / \mathrm{dl}$

- S. Proteins - $5.39 \mathrm{mg} / \mathrm{dl}$

- S. Albumin - $2.75 \mathrm{mg} / \mathrm{dl}$

- S. Globulins - $2.64 \mathrm{mg} / \mathrm{dl}$

- SGOT 65.30 IU/L

- $\quad$ SGPT $61.39 \mathrm{IU} / \mathrm{L}$

- $\quad$ S. ALP- $712.38 \mathrm{IU} / \mathrm{L}$

- S. Creatinine - $0.59 \mathrm{mg} / \mathrm{dl}$

- $\quad$ S. Urea - $29.56 \mathrm{mg} / \mathrm{dl}$

- S. Uric acid - $6.67 \mathrm{mg} / \mathrm{dl}$

- Prothrombin time

- On patient's blood $22.60 \mathrm{sec}$

- On control $13.30 \mathrm{sec}$

- $\quad$ APTT - $51.20 \mathrm{sec}$

- $\quad$ INR - 1.76.

Medicine reference was done and patient diagnosed as HELLP Syndrome. Four units of fresh frozen plasma were arranged and transfused immediately. Vitamin K loading dose was given. The drain kept on filling with blood that was around another $700 \mathrm{ml}$ six hours post-op. Further five more fresh frozen plasma were arranged and transfused. The total in drain was $1300 \mathrm{ml}$ around five hours later (add on time) then it stopped for next eight hours. Vitals of the patient were stable, her urine output was adequate, no distension per abdomen, no complaints from patient. The drain bag was emptied and when attached again a bolus of around $1000 \mathrm{ml}$ of blood got collected in the bag. The patient was shifted to medicine ICU. A total of around $2300 \mathrm{ml}$ of collection in drain bag that was bloody with one blood and nine fresh frozen plasma were transfused.

\section{Her day 2 post-op investigations were as follows}

- Hemoglobin $-8.1 \mathrm{~g} / \mathrm{dl}$

- TLC - $24400 \mathrm{cell} / \mathrm{mm}^{3}$

- Platelet count - $0.60 \mathrm{lac} / \mathrm{mm}^{3}$
- $\quad$ RDW - $20.2 \%$

- S. Bb (Total) - $7.22 \mathrm{mg} / \mathrm{dl}$

- $\mathrm{S} . \mathrm{Bb}$ (Direct) - $4.07 \mathrm{mg} / \mathrm{dl}$

- $\mathrm{S} . \mathrm{Bb}$ (Indirect) - $3.15 \mathrm{mg} / \mathrm{dl}$

- S. Proteins - $5.57 \mathrm{mg} / \mathrm{dl}$

- S. Albumin - $3.37 \mathrm{mg} / \mathrm{dl}$

- S. Globulins - $2.2 \mathrm{mg} / \mathrm{dl}$

- $\mathrm{SGOT}$ - $77.85 \mathrm{IU} / \mathrm{L}$

- $\quad$ SGPT - 67.49 IU/L

- $\quad$ S. ALP - 712.38 IU/L

- S. Creatinine - $1.96 \mathrm{mg} / \mathrm{dl}$

- S. Urea - $42.17 \mathrm{mg} / \mathrm{dl}$

- $\quad$ S. Uric acid - $11.29 \mathrm{mg} / \mathrm{dl}$

- Prothrombin time - $22.00 \mathrm{sec}$

- INR - 1.96.

Viral markers were negative for hepatitis B, C and E. Thyroid profile was normal. The drain however still had $500 \mathrm{ml}$ of collection that was turning serous. Another four units of fresh frozen plasma were arranged and transfused. Her vitals were stable although she now had an anemic and weak look. To her medications higher order antibiotics, haemostatic drugs, laxative syrup were given. Her day 3 investigations showed improvement in her coagulation profile but her liver function test deranged further and kidney functions also started deteriorating.

\section{Day 3 post-op investigations}

- Hemoglobin - $5.2 \mathrm{~g} / \mathrm{dl}$

- TLC - 30200 cell $/ \mathrm{mm}^{3}$

- Platelet count - $0.70 \mathrm{lac} / \mathrm{mm}^{3}$

- $\mathrm{RDW}-16.2 \%$

- S. Bb (Total) - $9.07 \mathrm{mg} / \mathrm{dl}$

- $\quad \mathrm{S} . \mathrm{Bb}$ (Direct) - $5.47 \mathrm{mg} / \mathrm{dl}$

- $\mathrm{S} . \mathrm{Bb}$ (Indirect) - $3.6 \mathrm{mg} / \mathrm{dl}$

- S. Proteins - $5.57 \mathrm{mg} / \mathrm{dl}$

- S. Albumin - $3.37 \mathrm{mg} / \mathrm{dl}$

- S. Globulins - $2.2 \mathrm{mg} / \mathrm{dl}$

- $\quad$ SGOT - 83.18 IU/L

- SGPT - 54.13 IU/L

- S. ALP - $712.38 \mathrm{IU} / \mathrm{L}$

- S. Creatinine - $2.15 \mathrm{mg} / \mathrm{dl}$

- $\quad$ S. Urea - $74.81 \mathrm{mg} / \mathrm{dl}$

- Prothrombin time - $20.60 \mathrm{sec}$

- $\quad$ INR - 1.83 .

Intra-abdominal septic foci were suspected as her counts were markedly raised, also she had slight distention of abdomen, her liver and kidney profile showed deteriorating values. Her blood and drain fluid were sent for culture.

Day 4 her liver function and kidney functions test further deteriorated and were as follows

- $\quad \mathrm{S} . \mathrm{Bb}$ (Total) - $11.14 \mathrm{mg} / \mathrm{dl}$ 
- $\quad \mathrm{S} . \mathrm{Bb}$ (Direct) $-7.52 \mathrm{mg} / \mathrm{dl}$

- $\mathrm{S} . \mathrm{Bb}$ (Indirect) $-3.62 \mathrm{mg} / \mathrm{dl}$

- S. Creatinine - $2.01 \mathrm{mg} / \mathrm{dl}$

- $\quad$ S. Urea - $124.78 \mathrm{mg} / \mathrm{dl}$.

A bedside ultrasound was done which showed mild ascites, mild hepatosplenomegaly, no obstruction in common bile duct, liver parenchyma normal, uterus postpartum bulky size. Her stich line was healthy. The patient was kept on intensive conservative management. One unit of blood and drugs to improve liver functions and kidney functions were further intensified.

The patient gradually recovered. Her liver function and kidney function tests started to show improvement. Her urine colour became better. Her stitches were completely removed on $10^{\text {th }}$ day with healthy stitch line. Finally, she was discharged on her $21^{\text {st }}$ post-operative day with a normal CBC, LFT and KFT.

\section{DISCUSSION}

Hypertensive disorders of pregnancy complicate up to $10 \%$ of pregnancies and constitute one of the major causes of maternal and perinatal morbidity and mortality worldwide. ${ }^{3}$ One of its serious complications HELLP syndrome (haemolysis, elevated liver enzymes, low platelet count) is not only a challenging but potentially a life-threatening condition. ${ }^{4}$

Patients with HELLP syndrome are at an increased maternal risk of complications such as: cerebral hemorrhage, retinal detachment, hepatic rupture, acute renal failure, disseminated intravascular coagulation, placental abruption, intrauterine foetal growth restriction sometimes intrauterine death and maternal death. There are many differential diagnoses to HELLP syndrome that include acute fatty liver of pregnancy, thrombotic thrombocytopenic purpura, antiphospholipid syndrome and hemolytic uremic syndrome.

\section{The presence of the following three criteria is required} for the diagnosis of HELLP

- Hemolysis (total bilirubin level of higher than 1.2 $\mathrm{mg} / \mathrm{dl}$ or decreased hemoglobin and hematocrit levels)

- Low platelet count (lower than 150000 cells $/ \mathrm{mm}^{3}$ )

- Elevated liver enzymes (aspartate aminotransferase level of higher than $40 \mathrm{IU} / \mathrm{L}$ and/or alanine aminotransferase level of higher than $40 \mathrm{IU} / \mathrm{L}){ }^{5}$

Adverse perinatal outcomes include preterm birth, low birth weight, the presence of foetal distress, low Apgar scores at 5 minutes.
The presence of HELLP syndrome involves a rapid termination of pregnancy and the administration of corticosteroids does not improve maternal morbidity and mortality but may help raise the platelet count, thus decreasing the need for transfusion and shorten hospital stay. ${ }^{6}$

\section{So to conclude HELLP syndrome}

- Symptoms/signs may be confusing

- Clinical presentation is unpredictable

- Aggressive supportive care required

- Significant cardiovascular outcome may ensue afterwards. $^{2}$

A decline in maternal morbidity and mortality associated with hypertensive disorders of pregnancy is in proper diagnosis and effective management of HELLP syndrome.

\section{Funding: No funding sources \\ Conflict of interest: None declared \\ Ethical approval: Not required}

\section{REFERENCES}

1. Stone JH. HELLP Syndrome: haemolysis, elevated liver enzyme and low platelets. JAMA. 1998;280:559-62.

2. Rao D, Chaudhari NK, Moore RM, Jim B. HELLP syndrome: a diagnostic conundrum with severe complications. Case Reports. 2016;2016:bcr2016216802.

3. Rimaitis K, Grauslyte L, Zavackiene A, Baliuliene V, Nadisauskiene R, Macas A. Diagnosis of HELLP Syndrome: A 10-year survey in a perinatology centre. Inter J Environ Res Pub Health. 2019;16(1):109.

4. Wallace K, Harris S, Addison A, Bean C. HELLP syndrome: pathophysiology and current therapies. Current Pharma Biotechnol. 2018;19(10):816-26.

5. Kınay T, Kayıkçıŏlu F, Küçük C, Karakaya J. Severe preeclampsia versus HELLP syndrome: maternal and perinatal outcomes. Balkan Med J. 2015;32(4):359-63.

6. Colín-Cortes HM, Ruvalcaba-Carrillo R, OlivaresRevilla DM, Yáñez-Torres JD, Flores-Rodríguez JL, Rodríguez-Figueroa N, et al. Hepatic subcapsular hematoma in HELLP syndrome. Report of 2 cases. Ginecol Obstet de México. 2018;86(6):412-9.

Cite this article as: Verma U, Agarwal S, Sahu S, Chahar A. Progressing haemolysis, elevated liver enzymes, low platelet count syndrome: near miss case Int J Reprod Contracept Obstet Gynecol 2020;9:2167-9. 